\title{
PERMAFROST OCGURRENCE IN THE FRONT RANGE, COLORADO ROCKY MOUNTAINS, U.S.A.
}

\author{
By JAGK D. Ives and BARry D. FAhEY \\ (Institute of Arctic and Alpine Research and Geography Department, University of Colorado, \\ Boulder, Colorado 80302 , U.S.A.)
}

\begin{abstract}
In contrast to the extensive and rapidly growing body of knowledge on permafrost in the Eurasian and North American Arctic and sub-Arctic, little is known about permafrost occurrence in the high mountain regions of the world. Preliminary results of permafrost studies from the Colorado Rocky Mountains are presented.

Above tree line (about $3500 \mathrm{~m}$ ) in the Front Range, scattered patches of permafrost begin to occur under wet sites blown free of snow in winter with a mean annual air temperature of about $-1.0^{\circ} \mathrm{C}$. At greater elevations, with correspondingly lower mean annual air temperatures (extreme case $-9.0^{\circ} \mathrm{C}$ and $4400 \mathrm{~m}$ ), permafrost becomes more extensive and probably exceeds $60 \mathrm{~m}$ in thickness. These initial results are derived from a skeleton ground-temperature observation program supplemented by indirect evidence and by data gathered from engineering and mining operations in the high country. It is probable that under the higher summits and ridge crests the alpine equivalent of the continuous zone of Arctic permafrost can be anticipated.
\end{abstract}

RÉsumé. Permafrost dans le Front Range, Colorado Rocky Mountains, U.S.A., Contrastant avec l'étendue et la rapide croissance des connaissances sur le permafrost dans les régions arctiques et subarctiques de l'Eurasie et de l'Amérique du Nord, faible est notre acquit concernant le permafrost dans les régions de haute montagne du globe. Les premiers résultas des études de permafrost dans les Colorado Rocky Mountains sont présentés.

Au dessus de la ligne de végétation forestière (environ $3500 \mathrm{~m}$ ) dans le Front Range, des taches éparses de permafrost commencent à apparaître dans les sites humides où le vent dégage la neige en hiver avec une température moyenne annuelle de l'air d'environ $-\mathrm{I}, \mathrm{o}^{\circ} \mathrm{C}$. Aux altitudes plus élevées, avec une température moyenne annuelle de l'air correspondante plus basse (cas extrême $-9,0^{\circ} \mathrm{C}$ et $440 \mathrm{om}$ ) le permafrost devient plus étendu et dépasse probablement $60 \mathrm{~m}$ en profondeur. Ces premiers résultats proviennent d'un programme réduit d'observations des températures du sol complété par des déductions indirectes et des données rassemblées à l'occasion de travaux de terrassement et d'exploitations minières dans les hautes régions. Il est probable que sous de sommets et des lignes de crête plus élevées l'existence d'un équivalent alpin aux zones continues de permafrost Arctique peut être présumée.

Zusammenfassung. Das Vorkommen von Permafrost in der Front Range, Colorado Rocky Mountains, U.S.A. Im Gegensatz zu dem reichen und schnell wachsenden Wissen über Permafrost in der eurasischen und nordamerikanischen Arktis und Subarktis ist über das Vorkommen von Permafrost in den Hochgebirgsregionen der Welt wenig bekannt. Vorläufige Ergebnisse von Permafrostuntersuchungen aus den Rocky Mountains in Colorado werden vorgelegt.

Oberhalb der Baumgrenze (etwa $3500 \mathrm{~m}$ ) tritt in der Front Range an einzelnen Stellen Permafrost unter feuchten, im Winter schneefrei geblasenen Flächen mit einem Jahresmittel der Lufttemperatur von $-1,0^{\circ} \mathrm{C}$ auf. In grösseren Höhen mit entsprechend niedrigeren mittleren Jahres-Lufttemperaturen (Extremfall $-9,0^{\circ} \mathrm{C}$ und $4400 \mathrm{~m}$ ) ist der Permafrost verbreiteter und übersteigt wahrscheinlich $60 \mathrm{~m}$ Mächtigkeit. Diese Anfangsergebnisse werden aus einem Programm zur Messung der Bodentemperatur nach der Rastermethode abgeleitet; sie werden durch indirekte Beobachtungen und Daten ergänzt, die bei Ingenieur- und Bergbauarbeiten im Hochland gesammelt wurden. Vermutlich darf unter den höheren Gipfeln und Kämmen das alpine Gegenstück zum zusammenhängenden arktischen Permafrostgürtel angenommen werden.

\section{INTRODUCTION}

Over the past 20 years a number of geologists and biologists have speculated upon the likelihood of permafrost occurrence above tree line in the Colorado Rocky Mountains, and specifically on Niwot Ridge, site of many research projects conducted through the Institute of Arctic and Alpine Research (INSTAAR). It is remarkable, however, that little effort has been invested in an attempt to substantiate or invalidate such speculation. Of particular interest are the inter-relationships between mean annual air temperature, mean annual ground temperature, incoming solar energy, snow depth and duration, soils, soil-moisture content, vegetation and periglacial activity. Permafrost research has been generally neglected in the mountain areas of the world (with slight exception, cf. the work of Pierce (196r) and Retzer (1956), there is a virtual absence of literature on permafrost in the Rocky 
Mountains) despite great expenditure of energy in Arctic and sub-Arctic regions (Sumgin and others, I940; Black, I954; Baranov, I959; Brown, I96o, 1966, I967, r969; Shumskiy, I955; Lachenbruch and others, I966; Péwé, I966).

The present report is an outline of the results of initial permafrost reconnaissance in the Front Range adjacent to INSTAAR's mountain research station. This work was carried out as a basis for detailed, long-term permafrost studies in western Colorado.

\section{IMMEDIATE FIELD AREA}

The INSTAAR mountain research station is situated in the sub-alpine forest belt at $2930 \mathrm{~m}$ on the east slope of the Front Range. The continental divide lies $12 \mathrm{~km}$ due west of the mountain research station, along which individual summits exceed $4000 \mathrm{~m}$. This section of the Front Range, known as the Indian Peaks, forms a remarkably straight ridge extending north-south for about $20 \mathrm{~km}$ between South Arapaho Peak (4086 m) in the south and Sawtooth Mountain $(3785 \mathrm{~m})$ in the north. The east slope of the Indian Peaks is dissected by a series of well-developed cirques, some containing diminutive glaciers, (cf. Outcalt and Benedict, I965) opening out into well-formed U-shaped valleys. Between the valleys, broad gently sloping interfluves extend approximately east-west; Niwot Ridge,

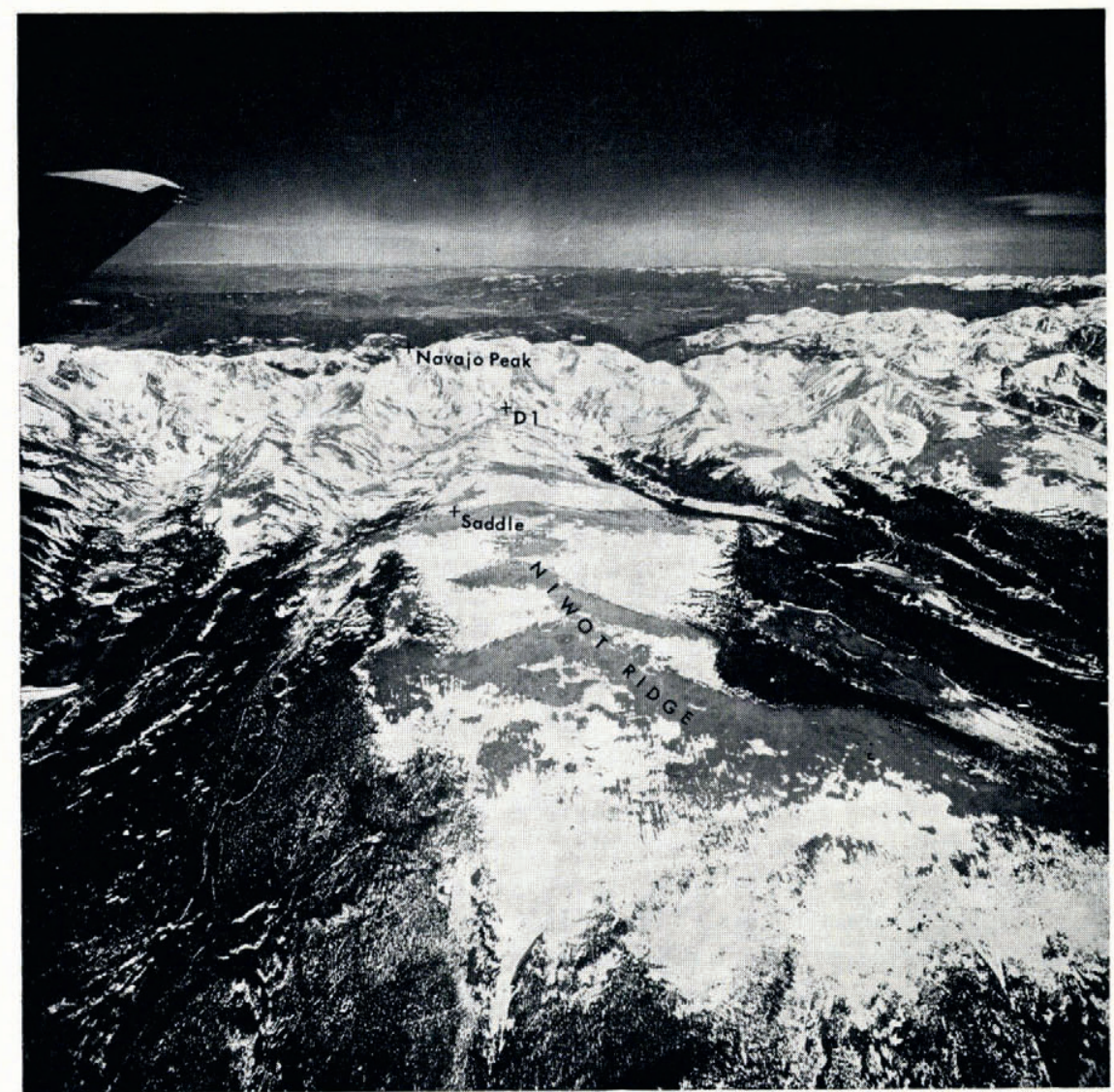

Fig. I. Aerial oblique view of the continental divide, Indian Peaks section, showing Niwot Ridge and the main permafrost research sile. 
which lies immediately above the mountain research station, is one of the most extensive having an above-tree-line area of about $20 \mathrm{~km}^{2}$. Tree line lies at about $3400 \mathrm{~m}$, above which the forest-tundra ecotone extends for a further 100 to $150 \mathrm{~m}$, finally grading into alpine tundra meadow, fellfield, semi-permanent snowbank and rock outcrop above about $3500 \mathrm{~m}$ (Fig. I). Benedict (1966, I967, I968, I970) has provided much valuable information on the periglacial environment of the alpine area, on its neoglacial chronology and on geomorphic processes operating today and in the recent past. The ecosystems of the Front Range have been described by Marr (I96I), and he has also tabulated climatic data for the period I95I-64 (Marr, I967; Marr, Clark and others, I968; Marr, Johnson and others, I968). A significant amount of additional botanical work has been undertaken by Wardle (1968), Osburn (1963[a], [b], i969), Gates and Janke (1965), and others.

The basic climatic parameters for Niwot Ridge, station altitude $3750 \mathrm{~m}$, based upon 17 years of continuous record are given in Table I.

Table I. Climatic data for Niwot Ridge station, $3750 \mathrm{~m}$
Mean annual air temperature
Mean July temperature
Mean January temperature
Mean monthly temperature range
Mean annual precipitation
Mean annual wind speed
Mean wind speed for November, December, January, February, March
Mean wind speed for January 1970

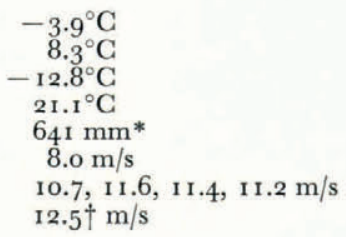
* Recent experiments with gauge screening indicate that the precipitation has probably been underestimated by $40-50 \%$.
$\dagger$ Highest monthly mean on record.

From the viewpoint of possible permafrost occurrence, the most significant climatological data are the relatively low mean annual air temperature and the very high mean wind speed for the winter months. The strong winter winds ensure that the broad ridge crests extending above tree line are largely snow-free throughout the snow accumulation period. April-May experiences the greatest snow cover, but by then the period of most intensive heat loss is past and heavy wet spring snow probably serves to reduce the warming process of the early summer by presenting a high albedo surface to the May-June-early July high-angle sun and by consuming much available energy in its melting process during this period.

\section{INITIAL INFERENCES}

Previous permafrost research experience in central Labrador-Ungava (Ives, I960, I961, 1962) prompted immediate comparison between this area and the Niwot Ridge alpine area on the first field visit in 1967 . In central Labrador-Ungava, typified by a comparable mean annual air temperature $\left(-4.4^{\circ} \mathrm{C}\right.$ ) but with a much greater annual amplitude (January mean $-21.6^{\circ} \mathrm{C}$; July mean $12.8^{\circ} \mathrm{C}$ ), it was shown that permafrost occurred extensively above the local tree line and especially beneath wind-swept ridges. Actual ground-temperature measurements recorded permafrost thicknesses of at least $60 \mathrm{~m}$ and led to the speculation that maximum thicknesses in excess of $90 \mathrm{~m}$ should be anticipated. In contrast, below the local tree line, or in other places where vegetation or topography facilitated the accumulation of snow, permafrost was thin, absent or deep-seated and relict.

Prior to the present study, assumptions concerning the presence or absence of permafrost in the Front Range, and in western Colorado in general, were scattered and contradictory. Retzer (I956) and Pierce (I96I) had reported on the occurrence of patches of permafrost, primarily in peaty soils, and R. Pennack (personal communication) had observed the persistence of frozen peat below tree line at $3200 \mathrm{~m}$ in a peat bog on the north side of Niwot 
Ridge; J. M. Clark (personal communication), on the other hand, from excavations at $375^{\circ} \mathrm{m}$ to a depth of $2 \mathrm{~m}$ in September, had concluded that, with the exception of patchy occurrences in peat, permafrost was not likely to be found extensively.

The initial comparison with central Labrador-Ungava is not particularly valid; this involves comparing a sub-Arctic environment with a lower-latitude (lat. $40^{\circ} \mathrm{N}$.) highaltitude situation without taking into account contrasts in solar-radiative energy and the annual temperature regime. However, it was thought that the mean annual air temperature at $375^{\circ} \mathrm{m}$ was sufficiently low to prompt more serious investigation. Brown (1967), on the basis of an extensive survey of the Russian literature, has indicated that, in the Arctic-sub-Arctic zone, the $-\mathrm{I}^{\circ}$ to $-2^{\circ} \mathrm{C}$ mean annual isotherm approximates the southern limit of permafrost, while the $-8^{\circ} \mathrm{C}$ mean annual isotherm approximates the transition between the discontinuous and continuous permafrost zones where permafrost thicknesses up to $60 \mathrm{~m}$ are widespread. Figure 2 is a simple plot of mean annual air temperature against altitude in the Front Range based upon 12 years of data from four stations and extrapolated up to $4400 \mathrm{~m}$ which approximates the altitude of nearby Mount Evans and Longs Peak.

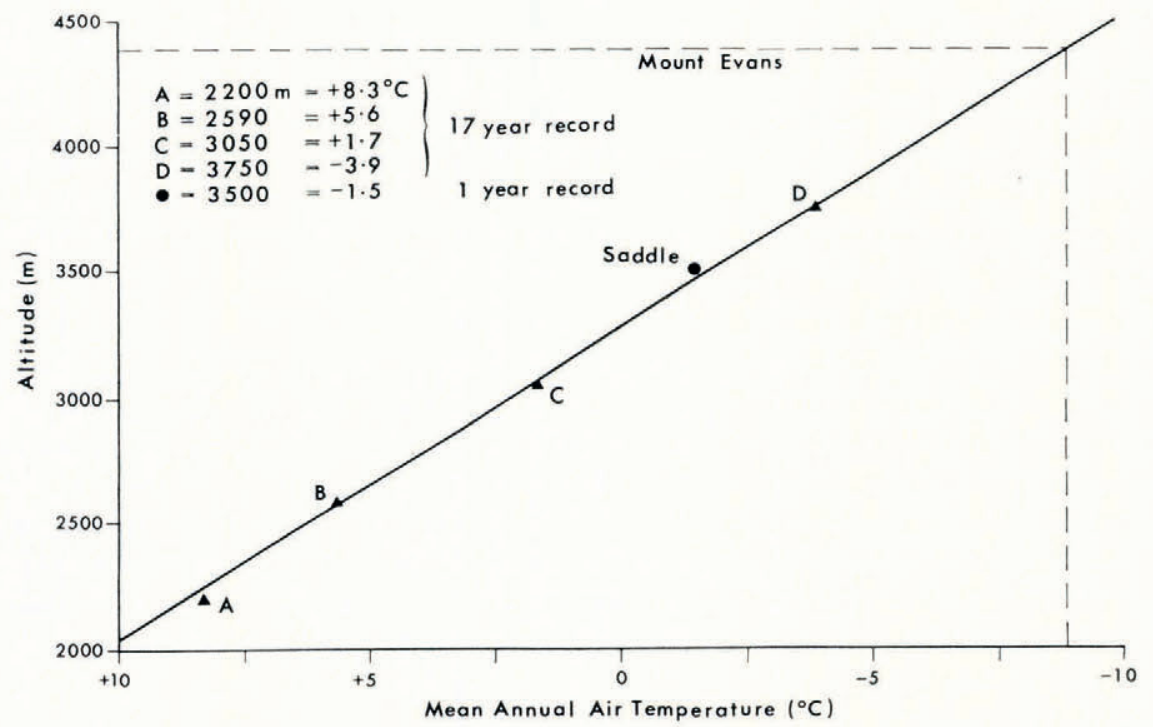

Fig. 2. Mean annual air temperatures at five sites on the east slope of the Front Range plotted against altitude.

\section{FieLd OBSERVATIONS}

As part of a study of freeze-thaw cycles and frost-heave/frost penetration through a range of altitudes (2 200-3 $750 \mathrm{~m})$, Fahey has maintained ground-temperature observations since July r968. His most interesting experimental plot, locally referred to as the Niwot Ridge "saddle site", lies at $3500 \mathrm{~m}$ on the tread of a large turf-banked lobe (Galloway, r96r; Benedict, I970). The actual site is characterized by an unknown depth of clayey silt-sand, active patterned ground and a high water table. Small ponds persist on the lobe surface through most of the summer, while strong winds keep the site snow-free for much of the winter. Pit excavations in mid-July 1968 revealed the presence of an ice layer I $\mathrm{m}$ below the surface. At the end of August, the thawed surface layer was still less than $2 \mathrm{~m}$ thick (maximum summer penetration $190 \mathrm{~cm}$ ). During the same period an adjacent thermistor probe at $200 \mathrm{~cm}$ depth remained fractionally below $0^{\circ} \mathrm{C}$ throughout the summer. Frost-depth indicators and continued thermistor readings have since confirmed the persistence of below- 
freezing temperatures at this site. Maximum depth to frozen soil recorded in late August 1969 was $183 \mathrm{~cm}$. Thus by definition (Muller, 1947) permafrost is proven, at least at this site.

During September and October I969, additional thermistors were installed between the saddle site $(3500 \mathrm{~m})$ and the western arête section of Niwot Ridge $(3800 \mathrm{~m})$. Depths to which thermistors could be installed, using a portable Atlas-Copco cobra drill varied between I and $5 \mathrm{~m}$. The drilling program was curtailed due to exceptionally heavy and early snowfall in October. However, sufficient observations have been obtained to permit the following conclusions:

I. At the $3500 \mathrm{~m}$ level under wet sites, permafrost occurs beneath an active layer less than $2 \mathrm{~m}$ thick. Freeze-back to the permafrost table was completed by early March in 1968 and by mid-February in 1969. Under nearby dry sites no below-freezing temperatures were recorded in October 1969 down to depths of $5 \mathrm{~m}$, although temperatures at this depth had fallen below the freezing point by mid-December 1969 . Mean annual air temperature in a standard screen for this elevation, based upon a single 12 month period of observation, is $-0.8^{\circ} \mathrm{C}$. Thus, at the $3500 \mathrm{~m}$ level, permafrost is probably restricted to wet sites, although it may occur under dry sites with an active layer in excess of $5 \mathrm{~m}$.

2. At the $375^{\circ}-3800 \mathrm{~m}$ level, permafrost occurs extensively under wet sites with an active layer less than $2 \mathrm{~m}$ thick. So far, the deepest thermistor installed at this level is $3 \mathrm{~m}$ in bedrock. In October 1969 , temperature at this depth was $+\mathrm{r}^{\circ} \mathrm{C}$; it had fallen below $0^{\circ} \mathrm{C}$ by 5 December 1969 . The implication here is that permafrost is probably widespread above $375^{\circ} \mathrm{m}$ and under dry sites the active layer is between 4 and $5 \mathrm{~m}$ thick.

3. Under the highest summits in the Front Range (4 $100-4400 \mathrm{~m})$, with an extrapolated minimum mean annual air temperature of $-9^{\circ} \mathrm{C}$, permafrost probably occurs to considerable thicknesses and can be classified as the alpine equivalent of the continuous Arctic permafrost zone.

Figure 3 shows the rate of freezing of the active layer at the saddle site and provides further indication that heat loss in winter significantly exceeds heat gain in summer.

\section{Substantiating EVIDENGE}

Mr W. Heon, mining engineer of Idaho Springs, has reported to us the occurrence of permafrost more than $30 \mathrm{~m}$ thick above tree line on Mt Lincoln $(4355 \mathrm{~m})$ situated on the continental divide east of Climax, Colorado. Mr Tom Platt, City of Boulder watershed engineer, has reported that bulldozers, moving till for dam fill struck frozen ground 3-4 $\mathrm{m}$ below the surface both in 1962 and 1965 in late summer. The bulldozing site was at 3 I $40 \mathrm{~m}$, below the Silver Lake reservoir on the south side of Niwot Ridge. This site, significantly, is below tree line but high winds keep the middle section of the valley inhospitable to tree-growth and blown free of snow.

Buildings installed at the summits of Pikes Peak and Mount Evans have undergone significant disturbance due to permafrost. In addition, several old-time miners and prospectors recollect difficulties with mining in frozen ground throughout a wide area of western Colorado during the late nineteenth-early twentieth century period.

On Niwot Ridge itself, many surface characteristics seem to provide supporting evidence:

i. Active patterned ground.

ii. Persistence of small ponds throughout summer.

iii. Persistence of small springs high on the ridge flanks; here it is inferred that the only possible water source is melting ground ice. 


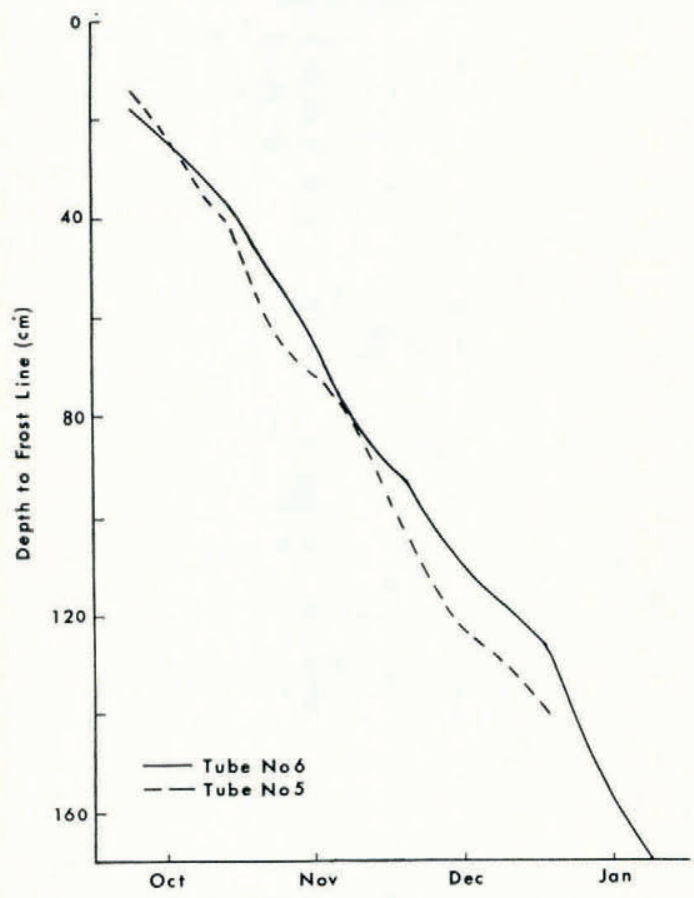

Fig. 3. Rate of frost penetration for mid-Oclober to mid-7anuary r969-7o at the "saddle site", Nizot Ridge, $3500 \mathrm{~m}$.

\section{Conglusions}

On the basis of the foregoing, it is believed that permafrost occurs at numerous sites above $3500 \mathrm{~m}$ in the Colorado Front Range and above $4000 \mathrm{~m}$ considerable thicknesses are likely to occur. It is also believed that, by comparison between the sites investigated in the Front Range and the other extensive alpine areas of western Colorado, permafrost should be anticipated over a wide region where high ridges and alpine valley floors are blown free of snow in winter.

\section{Acknowledgements}

The field work was supported by grants from the University of Colorado Council on Research and Creative Work and the Graduate School. Messrs Donald Alford, William M. Bower, Rolf Kihl and Eisaku Tsurumi assisted with the drilling operations. Dr Jerry Brown, Cold Regions Research and Engineering Laboratories, Hanover, New Hampshire, kindly made available the frost-depth indicators used in this study.

MS. received 8 July 1970

\section{REFERENCES}

Baranov, I. Ya. 1959. Geograficheskoye rasprostraneniye sezonnopromerzayushchikh pochv i mnogoletnemerzlykh gornykh porod [Geographical distribution of seasonally frozen ground]. (In Tsytovich, N. A., ed. Osnovy geokriologii (merzlotovedeniya) [Principles of geocryology (permafrost studies)]. Moscow, Izadtel'stvo Akademii Nauk SSSR, Tom I, p. r93-219.)

Benedict. J. B. 1966. Radiocarbon dates from a stone-banked terrace in the Colorado Rocky Mountains, U.S.A. Geografiska Annaler, Vol. 48A, No. I, p. 24-31. 
Benedict, J. B. 1967. Recent glacial history of an alpine area in the Colorado Front Range, U.S.A. I. Establishing a lichen-growth curve. Journal of Glaciology, Vol. 6, No. 48, p. 81 7-32.

Benedict, J. B. I968. Recent glacial history of an alpine area in the Colorado Front Range, U.S.A. II. Dating the glacial deposits. Fournal of Glaciology, Vol. 7, No. 49, p. 77-87.

Benedict, J. B. 1970. Downslope soil movement in a Colorado alpine region: rates, processes and climatic significance. Arctic and Alpine Research, Vol. 2, No. 3, p. 165-227.

Black, R. F. 1954. Permafrost-a review. Bulletin of the Geological Society of America, Vol. 65, No. 9, p. 839-55.

Brown, R. J. E. I96o. The distribution of permafrost and its relation to air temperature in Canada and the U.S.S.R. Arctic, Vol. 13, No. 3, p. 163-77.

Brown, R. J. E. 1966. The relation between mean annual air and ground temperatures in the permafrost region of Canada. (In U.S. National Research Council. Building Research Advisory Board. Proceedings of an international conference on permafrost. Washington, D.C., p. $24 \mathrm{I}^{\mathrm{I}} 46$. ([U.S.] National Academy of SciencesNational Research Council Publication 1287.))

Brown, R. J. E. 1967. Comparison of permafrost conditions in Canada and the U.S.S.R. Polar Record, Vol. 13, No. 87 , p. $741-51$.

Brown, R. J. E. I969. Factors influencing discontinuous permafrost in Canada. (In Péwé, T. L., ed. The periglacial environment, past and present. Montreal, McGill-Queen's University Press [and] Arctic Institute of North America, p. I I-53.)

Galloway, R. W. I961. Solifluction in Scotland. Scottish Geographical Magazine, Vol. 77, No. 2, p. 75-87.

Gates, D. M., and Janke, R. 1965. The energy environment of the alpine tundra. Oecologie Planta, Vol. I, p. $39-62$.

Ives, J. D. 196o. Permafrost in central Labrador-Ungava. Journal of Glaciology, Vol. 3, No. 28, p. 789-9o.

Ives, J. D. I961. A pilot project for permafrost investigations in central Labrador-Ungava. Geographical Papers (Ottawa), No. 28.

Ives, J. D. 1962. Iron mining in permafrost, central Labrador-Ungava. Geographical Bulletin (Ottawa), No. 17, p. $66-77$.

Lachenbruch, A. H., and others. 1966. Permafrost and geothermal regimes, by A. H. Lachenbruch, G. W. Greene and B. V. Marshall. (In Wilimovsky, N. J., and Wolfe, J. N., ed. Environment of the Cape Thompson region, Alaska. Oak Ridge, Tenn., U.S. Atomic Energy Commission, p. 149-63.)

Marr, J. W. I96r. Ecosystems of the east slope of the Front Range in Colorado. University of Colorado Studies. Series in Biology, No. 8.

Marr, J. W. 1967. Data on mountain environments. I: Front Range, Colorado. Sixteen sites, I952-53. University of Colorado Studies. Series in Biology, No. 27.

Marr, J. W., and others. I968. Data on mountain environments. II: Front Range, Colorado. Four climax regions 1953-58, by J. W. Marr, A. W. Johnson, W. S. Osburn and O. A. Knorr. University of Colorado Studies. Series in Biology, No. 28.

Marr, J. W., and others. I968. Data on mountain environments. III: Four climax regions, 1959-1964, by J. W. Marr, J. M. Clark, W. S. Osburn and M. W. Paddock. University of Colorado Studies. Series in Biology, No. 29.

Muller, S. W., comp. I943. Permafrost, or permanently frozen ground, and related engineering problems. U.S. Army. Office of the Chief of Engineers. Strategic Engineering Study No. 62.

Osburn, W. S., jr. I $963[\mathrm{a}]$. The dynamics of fallout distribution in a Colorado alpine tundra snow accumulation ecosystem. (In Schultz, V., and Klement, A. W., jr., ed. Radioecology. Proceedings of the first national symposium on radioecology, Colorado State University, Fort Collins, Colorado, September 1961. New York, Reinhold Publishing Corporation, p. $5 \mathrm{I}-7 \mathrm{I}$.)

Osburn, W. S., jr. 1963[b]. Influence of four Rocky Mountain regional environments on pea plants grown from irradiated sites. (In Schultz, V., and Klement, A. W., jr., ed. Radioecology. Proceedings of the first national symposium on radioecology, Colorado State University, Fort Collins, Colorado, September 196I. New York, Reinhold Publishing Corporation, p. $3^{1} 9^{-24}$.)

Osburn, W. S., jr. 1969. Primula parryi: correlation of morphological variability with background radioactivity. (In Nelson, D. J., and Evans, F. C., ed. Radioecology. Proceedings of the second national symposium on radioecology, Ann Arbor, Michigan, May I5-17, I967. Oak Ridge, Tenn. U.S. Atomic Energy Commission, p. 185-9o.)

Outcalt, S. I., and Benedict, J. B. 1965. Photo-interpretation of two types of rock glacier in the Colorado Front Range, U.S.A. Journal of Glaciology, Vol. 5 , No. 42, p. 849-56.

Péwé, T. L. 1966. Permafrost and its effect on life in the north. (In Hansen, H. P., ed. Arctic biology. Proceedings of the eighteenth annual biological colloquium held at Oregon State College, April 1957. Corvallis, Oregon State University, p. $3-40$.)

Pierce, W. G. I96r. Permafrost and thaw depressions in a peat deposit in the Beartooth Mountains, northwestern Wyoming. U.S. Geological Survey Professional Paper 424-B, p. ${ }^{5} 54-56$.

Retzer, J. L. 1956. Alpine soils of the Rocky Mountains. Fournal of Soil Science, Vol. 7, No. 1, p. $22-32$.

Shumskiy, P. A. I955. Osnovy strukturnogo ledovedeniya. Petrografiya presnogo l'da kak metod glyatsiologicheskogo issledovaniya. Moscow, Izdatel'stvo Akademii Nauk SSSR. [English translation: Principles of structural glaciology: the petrography of fresh-water ice as a method of glaciological investigation. Translated from the Russian by David Kraus. New York, Dover Publications, I964.]

Sumgin, M. I., and others. 1940. Obshcheye merzlotovedeniye [General permafrost studies]. [By] M. I. Sumgin, S. P. Kacharin, N. I. Tolstakhin and V. F. Tumel. Moscow, Izdatel'stvo Akademii Nauk SSSR.

Wardle, P. I968. Engelmann spruce (Picea engelmannii Engel.) at its upper limits on the Front Range, Colorado. Ecology, Vol. 49, No. 3, p. 483-95. 